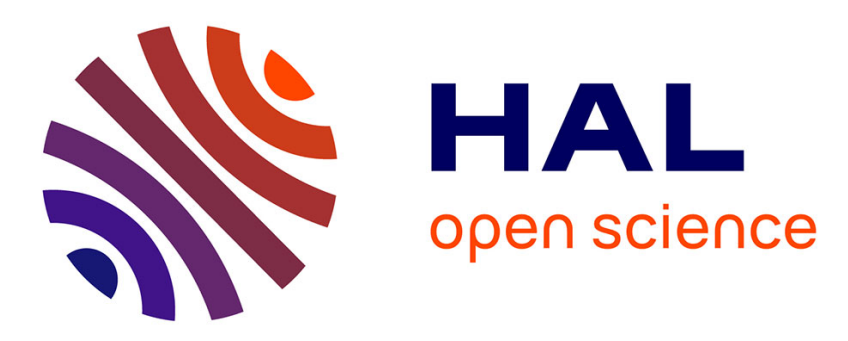

\title{
To be or not to be: postcubital vein in insects revealed by microtomography
}

Thomas Schubnel, Laure Desutter-Grandcolas, Frédéric Legendre, Jakub Prokop, Arnaud Mazurier, Romain Garrouste, Philippe Grandcolas, André $\mathrm{Nel}$

\section{To cite this version:}

Thomas Schubnel, Laure Desutter-Grandcolas, Frédéric Legendre, Jakub Prokop, Arnaud Mazurier, et al.. To be or not to be: postcubital vein in insects revealed by microtomography. Systematic Entomology, 2019, 10.1111/syen.12399 . hal-02349207

\section{HAL Id: hal-02349207 https://hal.science/hal-02349207}

Submitted on 5 Nov 2019

HAL is a multi-disciplinary open access archive for the deposit and dissemination of scientific research documents, whether they are published or not. The documents may come from teaching and research institutions in France or abroad, or from public or private research centers.
L'archive ouverte pluridisciplinaire $\mathbf{H A L}$, est destinée au dépôt et à la diffusion de documents scientifiques de niveau recherche, publiés ou non, émanant des établissements d'enseignement et de recherche français ou étrangers, des laboratoires publics ou privés. 
1 To be or not to be: postcubital vein in 2 insects revealed by microtomography

3

4

THOMAS SCHUBNEL ${ }^{1}, \quad$ LAURE DESUTTER-GRANDCOLAS ${ }^{1}, \quad$ FREDERIC LEGENDRE $^{1}$, JAKUB PROKOP ${ }^{2}$, ARNAUD MAZURIER ${ }^{3}$, ROMAIN GARROUSTE $^{1}$, PHILIPPE GRANDCOLAS ${ }^{1}$ and ANDRE NEL ${ }^{1}$

${ }^{1}$ Institut Systématique Evolution Biodiversité (ISYEB), Muséum national d'Histoire naturelle, CNRS, Sorbonne Université, EPHE, Université des Antilles, 57 rue Cuvier, CP 50, 75005 Paris, France.

${ }^{2}$ Department of Zoology, Faculty of Science, Charles University, Viničná 7, CZ-128 00 Praha 2, Czech Republic.

${ }^{3}$ IC2MP UMR 7285 - Université de Poitiers - UFR SFA, Bâtiment B35, TSA 51106, 6 rue Michel Brunet, 86073 Poitiers cedex 9, France.

Short title: $\mathrm{PCu}$ vein in insects

\section{Abstract.}

To better understand insect evolution, fossils - mainly known by their wings - must be used as terminals in phylogenetic analyses. Such analyses are, however, rarely performed because of a lack of consensus on the homology of venation in insects. Authors do not agree with current concept on the exact number and the identity of the main veins. Here, we confirm the presence, questioned since the early twentieth century, of an independent main postcubital vein $(\mathrm{PCu})$ between the cubital and anal veins (29 fossil and extant examined orders, $>85 \%$ of observed insects). The vein $\mathrm{PCu}$ corresponds to the so-called vein $1 \mathrm{~A}$ or first anal vein. It is easily 
identified by the unique shape of its bulla. It may have several branches, and be partially fused with the cubital and anal veins. Once the PCu vein identified, we reconsidered as an example the particular case of the Phasmatodea, showing that extant stick insects have a unique venation among insects, with a reduced median vein, and a simple cubital vein, adjacent or fused to the $\mathrm{PCu}$. This study is a new approach towards resolving wing vein homology issues, crucial for future large-scale phylogenetic analyses in insects combining extant and extinct taxa.

\section{Introduction}

Although thousands of fossil insects have been described over the last twenty years, these extinct taxa are included in phylogenetic analyses only rarely enough (Misof et al., 2014; Wang et al., 2016). They are merely used for their temporal dimension as calibration points in dating estimates, whereas they can also bring original evolutionary evidence (i.e. new states of characters, new combinations of character states, new taxa). Taking this evolutionary information into account, and thus taking full advantage of those fossils, requires advances in primary homology of wing veins. Indeed, as the best-preserved structures of fossil insects, wing veins are critical to better understand the deep-past evolution of insects - as recently shown for some orders (e.g., Nel et al., 2012; Prokop et al., 2014, 2018; Jacquelin et al., 2018). Yet, despite two centuries of efforts, the homologies of wing veins remain an open question. Authors do not agree on the exact number of main veins (see below), let alone their homologies (e.g., Comstock \& Needham, 1898, 1899; Snodgrass 1935; Kukalová-Peck, 1991).

Wings are complex structures containing nerves, sensillae, and tracheae, all more or less connected to veins (Chapman, 1998). Veins can fork, vanish, be fused (Jacquelin et al., 2018), or change their convexity (a convex vein, when seen from above, is in a higher position than a concave one), so many modifications that may explain why no consensus yet exists as to the number and identity of insect veins. From six to eight main longitudinal veins are thus 
classically considered in insect wings, the area between the cubital and anal complexes being the main area of conflict (Table 1).

Among those conflicts (Table 1), the vein between the cubital and anal complexes has been identified either as a vein named postcubital or empusal vein ( $\mathrm{PCu}$ or $\mathrm{E})$, independent of the cubital or anal stems (e.g., Lameere, 1922; Snodgrass, 1935; Hamilton, 1972; Emeljanov, 1977), or as the first anal vein attached to the anal stem (e.g., Comstock \& Needham, 1898, 1899; Wootton, 1979; Kukalová-Peck, 1992). Authors brought various evidences using different criteria to refine their homology hypotheses (e.g., tracheae, axillary sclerites, folds of wings). They also recognized that all of these criteria, when used individually, have defects (Hamilton, 1972) so that no hypothesis has received unanimous support (e.g., Matsuda, 1970 contra Wootton, 1979). Thus, the exact nature and the existence of an independent postcubital vein between the cubital and anal veins remain unsolved and hinder sound homology hypotheses at the largest insect scale.

Consequently, several venation groundplans exist and are currently used to describe insect venation. Most authors use the venation terminology proposed by Comstock \& Comstock (1895), modified by Comstock \& Needham (1898, 1899), and summarized by Comstock (1918). Kukalová-Peck (1991) proposed a second groundplan also currently used. A third proposal of groundplan with a further $\mathrm{PCu}$ vein between $\mathrm{Cu}$ and $\mathrm{A}$, originally proposed by Lameere (1922) (PCu as 'Pénultième' vein) and partly followed by Forbes (1943) (PCu as Plical vein or Pl), was supported by Snodgrass (1935), Matsuda (1970), Emeljanov (1977), and Brodsky (1994). It was followed incidentally for Trichoptera and Lepidoptera (Ivanov, 1985, 1995), more frequently for Hemiptera (e.g., Franielczyk-Pietyra \& Wegierek, 2019), and very recently for Blattodea (Li et al., 2018). The PCu vein corresponds to the anterior anal vein (AA) of Kukalová-Peck (1991) and to the first anal branch of Comstock (1918), as already noticed by Séguy (1959: 50) (Table 1). 
Table 1 : Comparison of different wing veins nomenclatures, with influence on the primary homologies. Terminology: a specific color was assigned for each homologous structure, viz., precostal stripe (PC), costa $(C)$, subcosta $(S c)$, radius $(R)$, sector $(S)$, media $(M)$, cubital $(C u)$, plical $(P)$, postcubitus $(P C u)$, empusal (E), anal (A), jugal (J).

\begin{tabular}{|c|c|c|c|c|c|c|c|c|c|c|c|}
\hline Comstock \& Needham (1898) & -- & C & Sc & \multicolumn{2}{|c|}{$\mathrm{R}$} & M & \multicolumn{2}{|c|}{$\mathrm{Cu}$} & 1st A & A & -- \\
\hline $\begin{array}{l}\text { Snodgrass (1935) } \\
\text { Emeljanov (1977) }\end{array}$ & -- & C & Sc & \multicolumn{2}{|c|}{$\mathrm{R}$} & M & \multicolumn{2}{|c|}{$\mathrm{Cu}$} & $\mathrm{PCu}$ & $\mathrm{A}$ & -- \\
\hline Hamilton (1972) & -- & C & Sc & $\mathrm{R}$ & $\mathrm{S}$ & M & $\mathrm{Cu}$ & $\mathrm{P}$ & E & A & -- \\
\hline Kukalová-Peck (1992) & $\mathrm{PC}$ & $\mathrm{C}$ & $\mathrm{Sc}$ & \multicolumn{2}{|c|}{$\mathrm{R}$} & M & \multicolumn{2}{|c|}{$\mathrm{Cu}$} & AA & $\mathrm{AP}$ & $\mathrm{J}$ \\
\hline
\end{tabular}

The origin of veins at the extreme base of wings must be observed to clarify vein homologies and resolve incongruities between the different venation patterns. Those observations are now possible because of adequate tools such as microtomography methods. Here, we use these tools in addition to direct optical observations to investigate the presence of the postcubital vein in the neopteran clades and in the Palaeodictyoptera fossils. We clarify the homologies of wing veins for those insects and illustrate the aftermath of this clarification using Phasmatodea, whose unusual venation has always been challenging (Ragge, 1955; Nel \& Delfosse, 2011; Wang et al., 2014).

\section{Material and methods}

\section{Wing venation terminology and color code:}

precostal stripe $(\mathrm{PC})$, costa $(\mathrm{C}$, in cyan), subcosta $(\mathrm{Sc}$, in red), radius ( $\mathrm{R}$, in magenta), media (M, in blue), cubital $(\mathrm{Cu}$, in yellow), postcubitus $(\mathrm{PCu}$, in white), anal (A, in black), jugal (J). Each vein ( $\mathrm{x}$ ) is supposed to have a (convex) anterior branch (xA) and a (concave) posterior branch (xP) (Lameere, 1922; Kukalová-Peck, 1991). The bulla of the vein (x) is identified as $\mathrm{xB}$.

Criteria for venation homology:

many criteria have been used to identify and postulate homology hypotheses on insect wing veins: the relative positions of veins, their polarities (convexity vs. concavity), the potential 
correspondence between the courses of tracheae (air transport) and veins (hemolymph transport), or the structures of the extreme wing bases (see discussion on the interests and limits of these criteria in Desutter-Grandcolas et al., 2017). Snodgrass (1935), Emeljanov (1977), Brodsky (1994), and Li et al. (2018), who all recognized a postcubital vein (PCu), based their results on alleged correspondences between the courses of the tracheae ' $\mathrm{Cu}$ ', ' $\mathrm{PCu}$ ' and ' $\mathrm{A}$ ' in the nymphal wing pads and in adult wings, being basally well separated in many insects. Because counter-examples of such correspondences have been demonstrated (Fraser, 1938; Smart, 1956; Whitten, 1962; Wootton, 1992), this criterion is insufficient to accurately establish the existence of the $\mathrm{PCu}$ vein.

Most often, only direct observations with optic binoculars have been used but they are limited by the intricate and hidden structures located at the base of the wings. Recently, the advents of X-ray microtomography methods (e.g., $\mu \mathrm{CT}$-scan, Synchrotron) blew a technological lock to answer problems of insect venation (Desutter-Grandcolas et al., 2017; Jacquelin et al., 2018). After these studies, a main vein is considered as independent from the other main veins if its own base, i.e. its 'bulla basivenale', is independent of all other bullae, even though all the bullae share a common base, corresponding to the main cavity of the insect thorax. These bullae are hidden inside the very base of the wing and they generally differ from the external plates or sclerites of the wing base. With X-ray microtomography methods and 3D reconstruction based on non-automatic careful segmentation, bullae can be distinguished and each of them related to a main vein.

\section{Taxonomic sampling:}

We observed 74 extant and fossil specimens from all the Pterygota superorders (Palaeodictyopterida, Ephemeroptera, Odonatoptera, Polyneoptera, Acercaria, Holometabola). Nine of them were scanned with X-ray microtomography. A complete list of the observed specimens and technical characteristics of scans are given in supplementary material (see Supplementary tables 1,2$)$. 
121 We tested the variability of the structures of the wing base in three groups, viz. Orthoptera,

122 Dictyoptera, and Phasmatodea. They were selected because, before conducting this study, we

123 had already realized several observations in those three taxa. We found a high intraordinal

124 stability for all veins including the $\mathrm{PCu}$ that appeared as a constant character that varied very

125 little in position and shape. It allows us to claim that the character state 'presence of a $\mathrm{PCu}$ ' is

126 stable within an order, except when drastic reductions of venation occur, as in Tridactylidae, a

127 family of Orthoptera where only one or two veins are still present in the wings. Consequently,

128 the observation of few specimens is sufficient to evaluate the presence / absence of a PCu.

129 Observed extant specimens were chosen following three main criteria: we selected specimens

130 that were numerous in the MNHN collections or easily available because we often needed to

131 damage the insects before observing them efficiently (e.g., we removed the scales of

Lepidoptera or cut the pronotum of cockroaches and Orthoptera); we preferred large specimens to make observations easier; we used a phylogenetic criterion when observing multiple insects from the same order to maximize the diversity (e.g., specimens from different suborders of Plecoptera, Coleoptera, Trichoptera).

Also, we used as many fossils as possible although their phylogenetic placements are often unclear and their wing bases are frequently not preserved. Fossils are indeed mandatory for extinct clades such as Palaeodictyopterida and Permopsocida. They are also useful to document past venation patterns.

141 We used the parsimony method with Winclada v.1.00.08 (Nixon, 2002) to reconstruct the ancestral states for the character 'presence of a $\mathrm{PCu}$ ' in insects. We used a simplified tree

143 derived from the phylogeny of Wipfler et al. (2019: Fig. 1), with 'Protelytroptera' as sister 144 group of Dermaptera (Béthoux et al., 2016), Palaeodictyopterida within Palaeoptera, 145 Hypoperlida as sister group of crown Acercaria (Prokop et al., 2017) and Permopsocida as sister group of (Hemiptera + Thysanoptera) (Huang et al., 2016). We performed two ancestral state 
reconstructions: one with the state '?' for taxa we are unsure about the presence of a PCu (i.e.

taxa with reduced wings or venations - see below); one with the state ' 0 ' (i.e. absence) for those

149 taxa. The former corresponds to our current state of knowledge; it is thus our main result. The

150 latter was performed only to assess whether our conclusions about PCu origin would still be

151 supported if those problematic taxa truly lack a PCu (this coding is however highly hypothetical

152 at this stage).
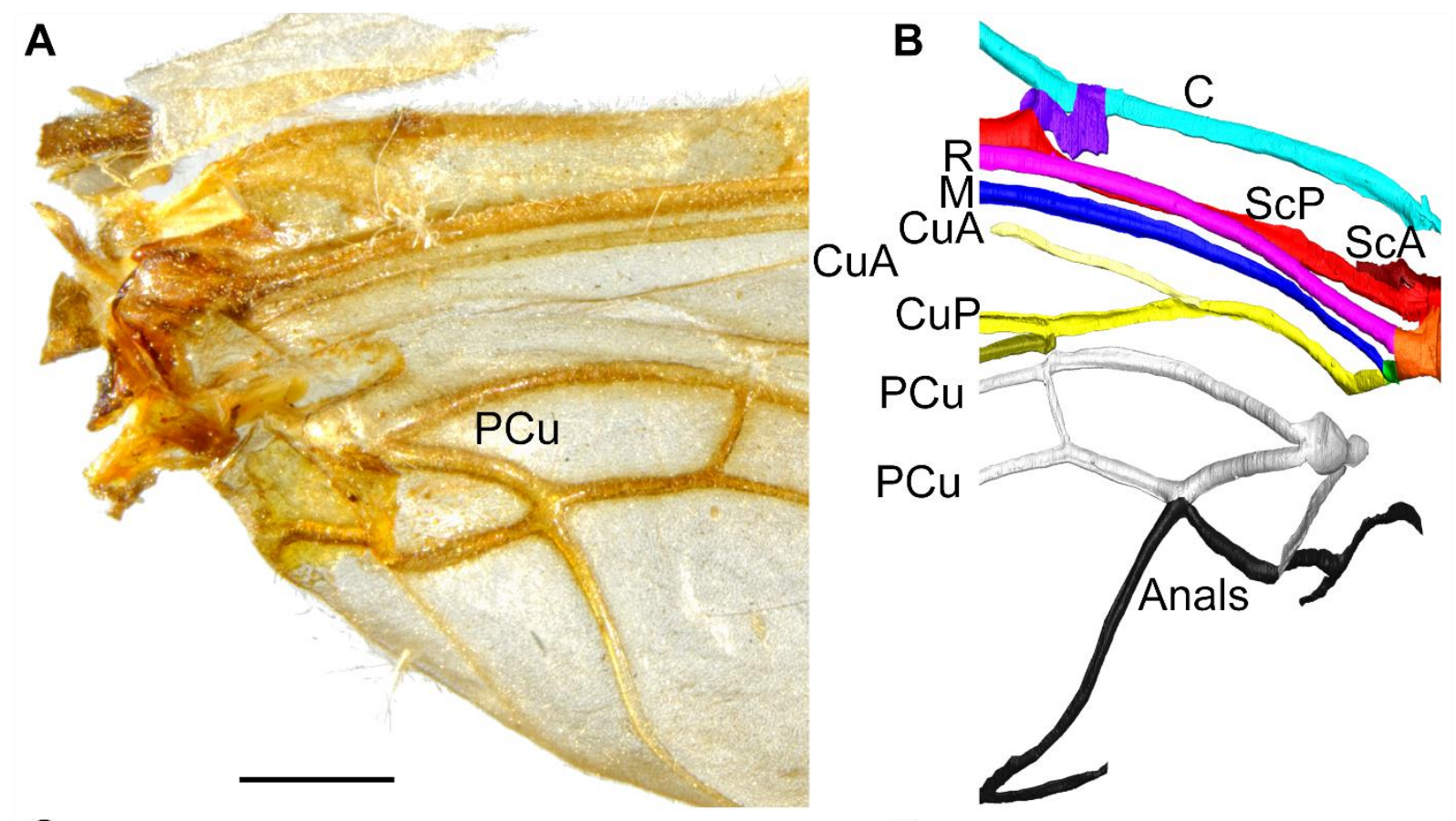

C
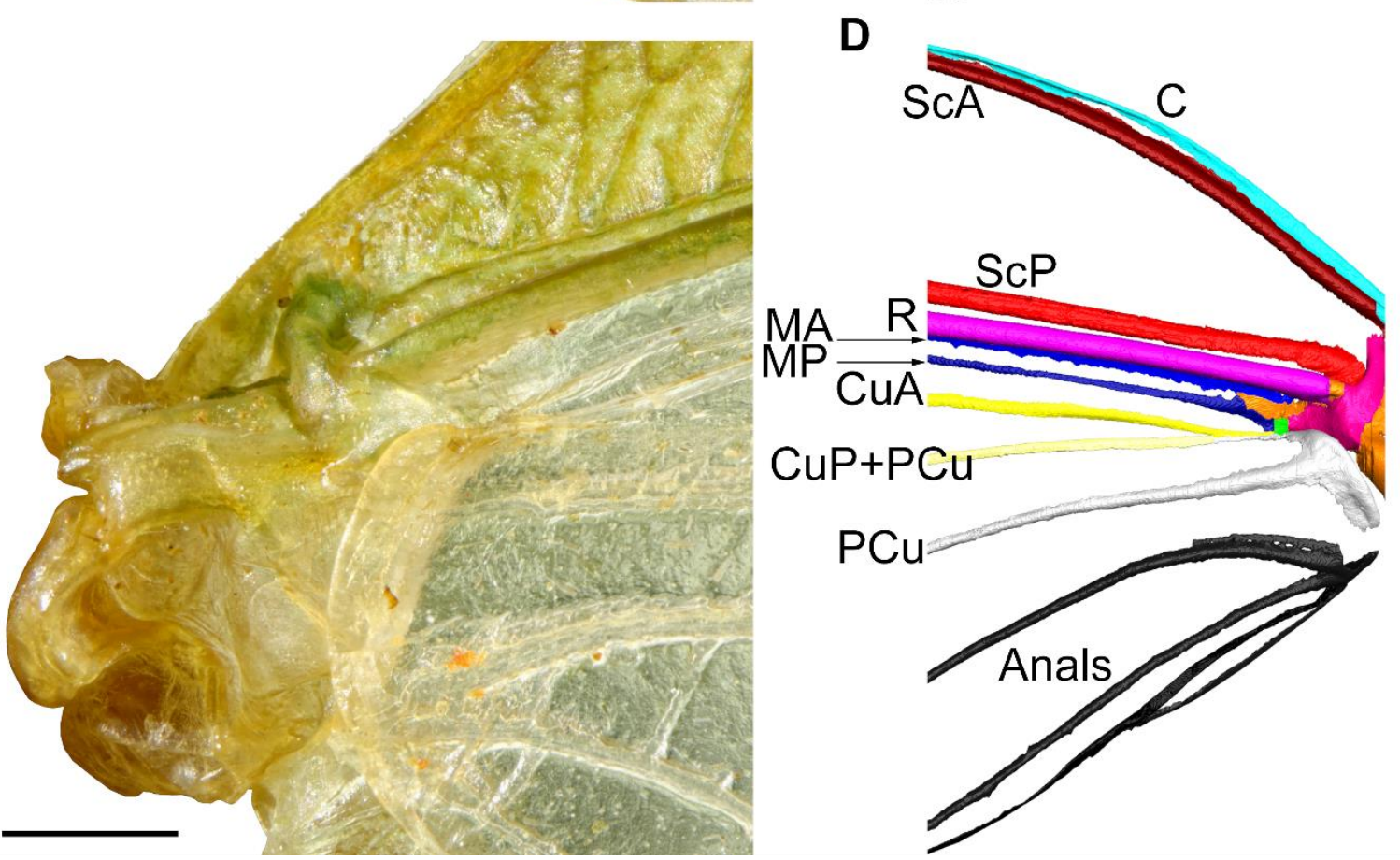

Fig. 1 : Forewing bases, photographs and 3D reconstructions, dorsal views. (A-B) Plecoptera Perla marginata (Panzer, 1799); (C-D) Mantodea Stagmatoptera supplicaria (Stoll, 1813). (copyright Thomas Schubnel). Scale bars $=1 \mathrm{~mm}$. 

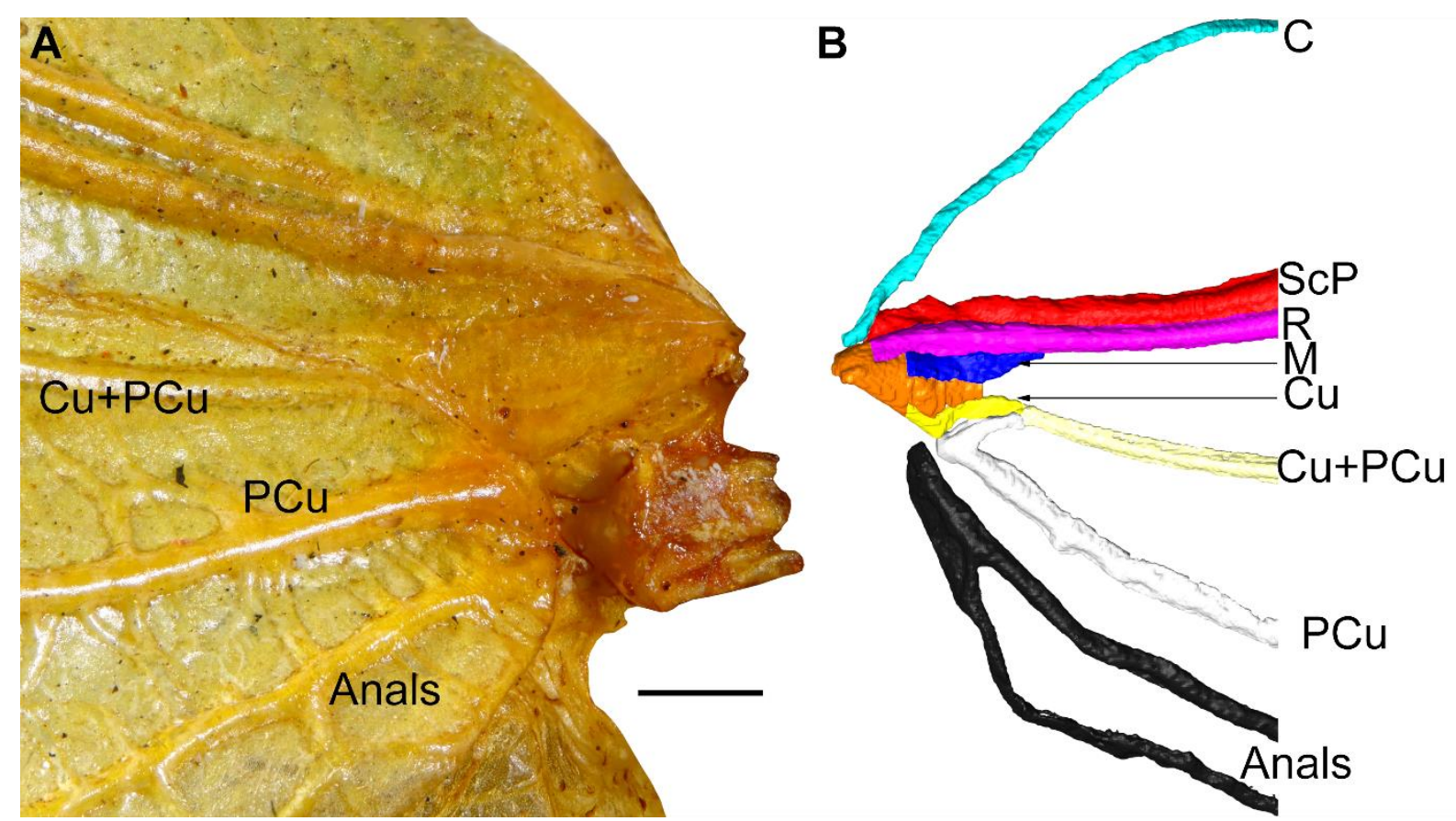

Fig. 2 : Forewing base, dorsal views. Phasmatodea Phasma gigas (Linnaeus, 1758). A, photograph; B, $3 D$ reconstructions. (copyright Thomas Schubnel). Scale bars $=1 \mathrm{~mm}$.

153

154

155

156

\section{Results and Discussion}

\section{Bullae vs external sclerites:}

The argument of Wootton (1979: 90) for a rejection of the hypothesis of an independent PCu

does not stand because it is based on the supposed origin of the veins on the external sclerites.

Yet, it is generally not the case after our X-ray microtomography observations: veins emerge from bullae, not from external sclerites. Odonatoptera, Ephemeroptera, and Palaeodictyoptera are exceptions with veins emerging from bullae and also connected to the basal sclerites (Prokop et al., 2018; Jacquelin et al., 2018).

\section{Identification of the PCu from its characteristic bulla:}

With the microtomography tools and $3 \mathrm{D}$ reconstruction by segmentation, we observed an independent bulla between the bullae of the cubital and anal veins in representatives of the following orders: stoneflies (Plecoptera) (Figs 1A-B, Supplementary Fig. 1), mantises (Mantodea) (Figs 1C-D, Supplementary Fig. 2), cockroaches (Blattodea), katydids, crickets, grasshoppers (Orthoptera), phasmids (Phasmatodea) (Figs 2A-B), webspinners (Embioptera), and beetles (Coleoptera). This bulla is characterized by its large, domed, convex, often 

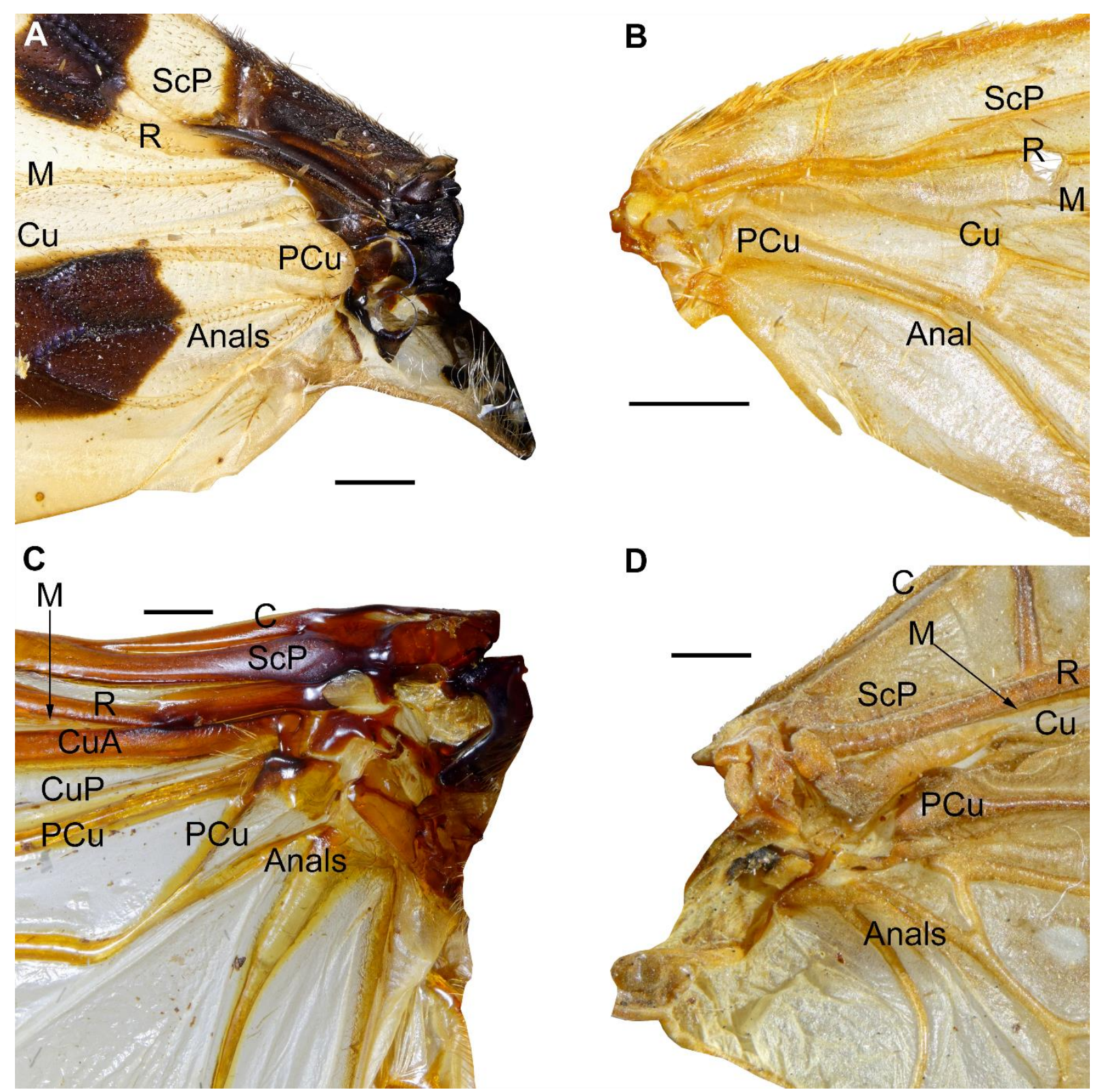

Fig. 3 : Forewing bases, photographs, dorsal views. A, Trichoptera Semblis phalaenoides (Linnaeus, 1758); B, Lepidoptera Korscheltellus lupulinus (Linnaeus, 1758); C, Coleoptera Oryctes sp.; D, Megaloptera Corydalus sp.; (copyright Thomas Schubnel). Scale bars $=1 \mathrm{~mm}$.

posteriorly curved structure, a set of features that allowed us to properly recognize it with a

binocular microscope (Figs 1A,C, 2A, 3-6).

Presence of the PCu in most winged insects:

171 Because of its peculiar set of features and of its relative position, the PCu can be easily

172 identified with a binocular microscope. In this way, we identified a bulla with the same shape

173 directly posterior to cubital veins in true bugs (Hemiptera: Sternorrhyncha Psyllidae,

174 Auchenorrhyncha Cicadellidae, Cercopidae, Fulgoridae, Cicadidae; Heteroptera Pentatomidae)

175 (Figs 5A-B), in which it corresponds to the bulla of the vein currently named PCu after 

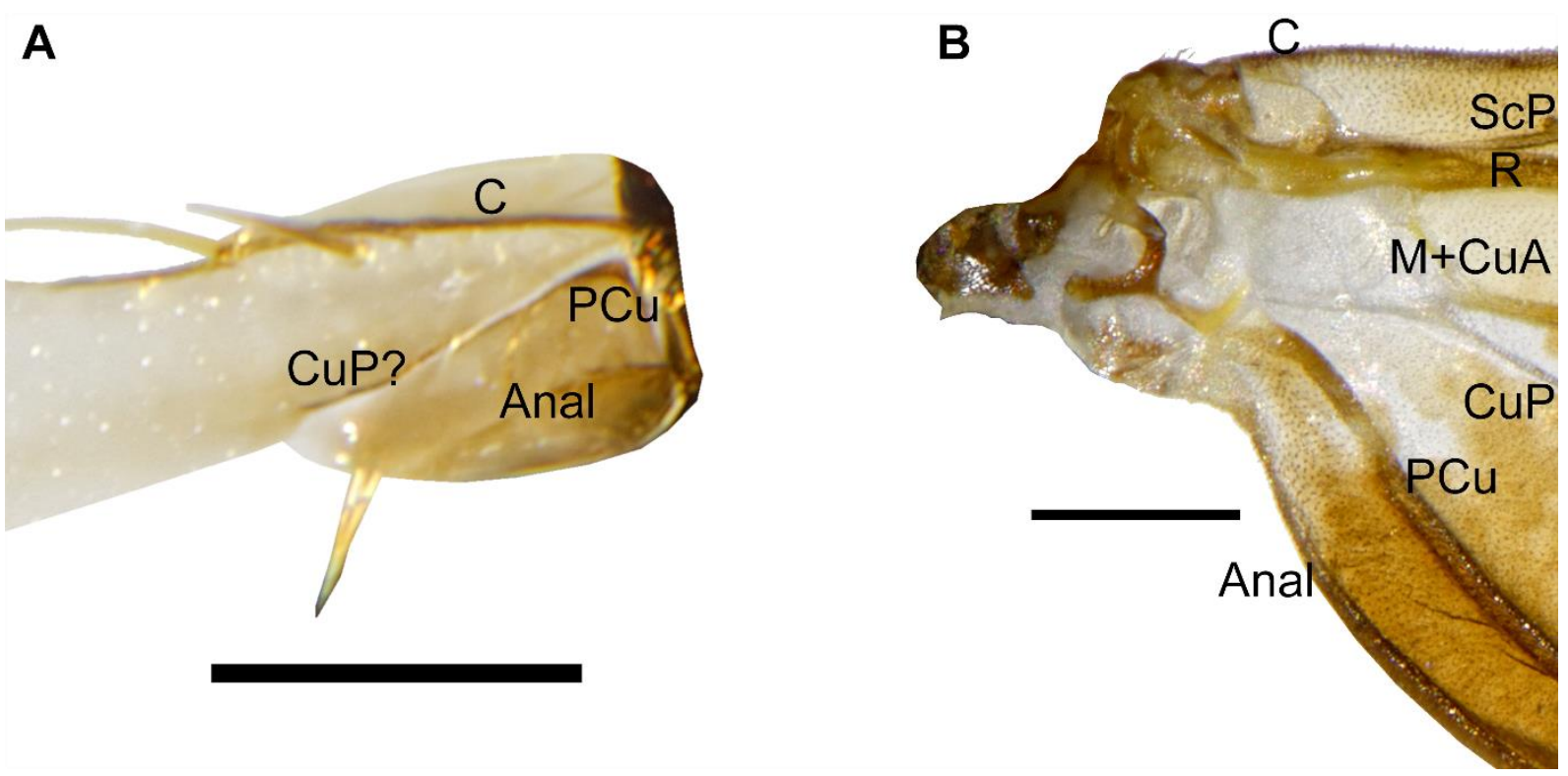

Fig. 5 : Forewing bases, photographs, dorsal views. A, Psocodea: Liposcelididae Loensia fasciata (Fabricius, 1787); B, Thysanoptera: Phaeothripidae Megalothrips delmasi Bournier, 1956. (copyright Thomas Schubnel). Scale bars $=0.25 \mathrm{~mm}$.

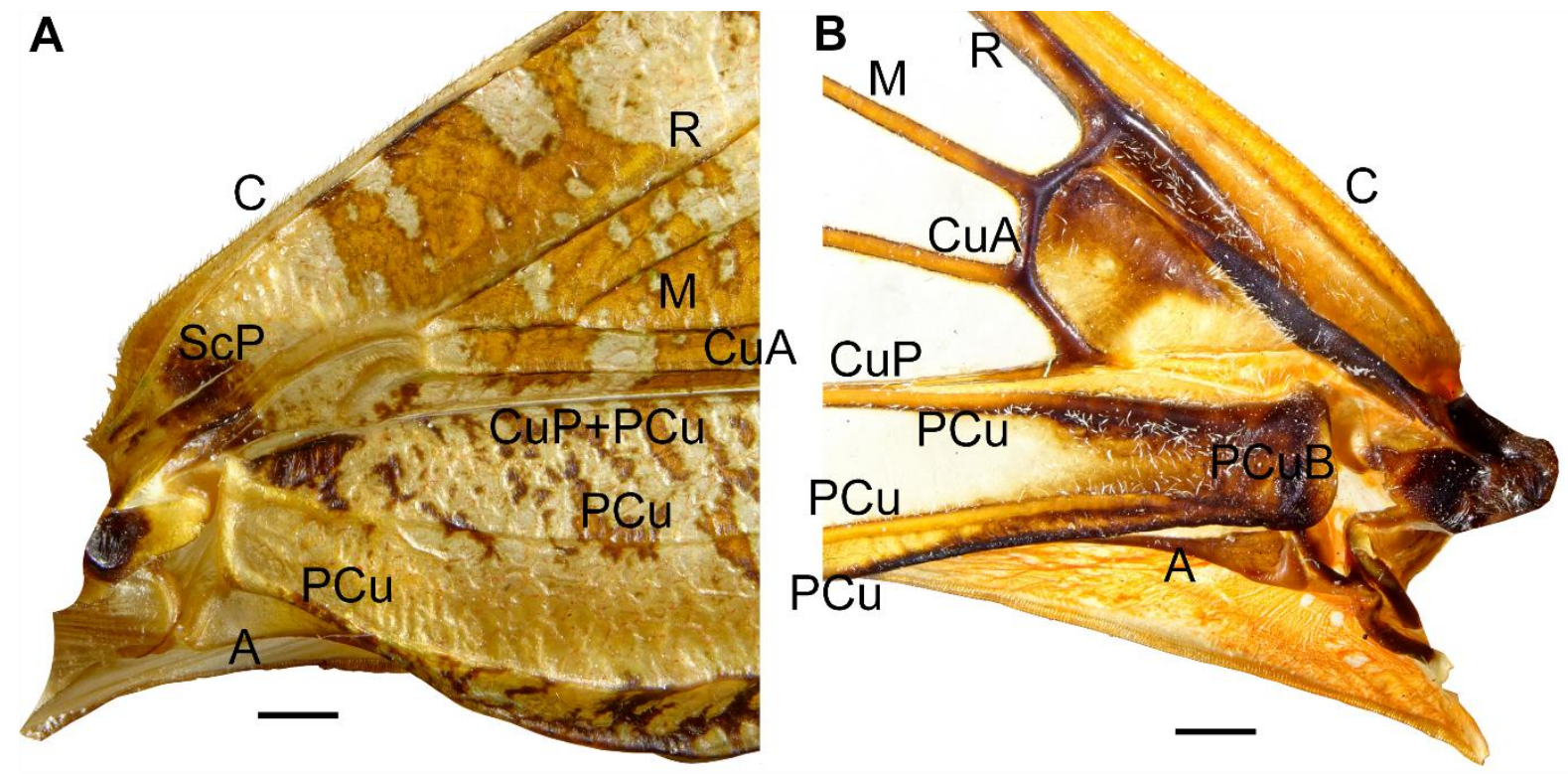

Fig. 4 : Forewing bases of Hemiptera, photographs, dorsal views. A, Fulgoridae Phrictus auromaculatus Distant, 1905; B, Cicadidae Lyristes plebejus (Scopoli, 1763). (copyright Thomas Schubnel). Scale bars $=1 \mathrm{~mm}$.

Emeljanov (1977) with its characteristic domed structure. We also observed this bulla in termites (Isoptera: Mastotermitidae, other termites have reduced venations), scorpionflies (Mecoptera: Panorpidae, Bittacidae), caddisflies (Trichoptera: Phrygaenidae, Molannidae,

Sericostomatidae, $\uparrow$ Necrotaulidae, Philopotamidae) (Fig. 3A), moths (Lepidoptera: Hepialidae,

Micropterigidae, and Agathiphagidae, confirmed from Ivanov (1995: figs 3-4) for the two later)

(Fig. 3B), lacewings (Neuroptera), beetles (Coleoptera: Cerambycidae, Scarabaeidae) (Fig. 

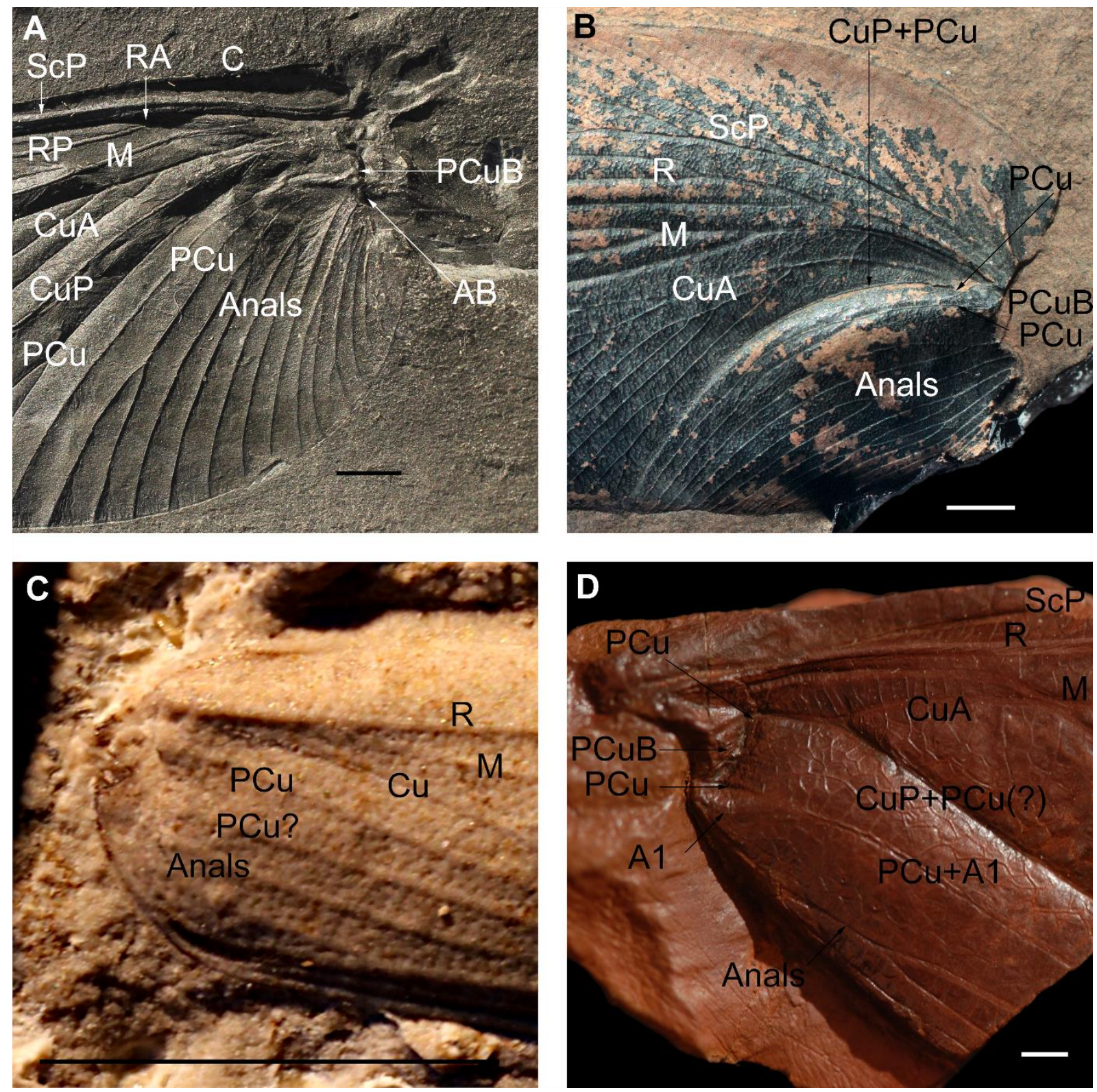

Fig. 6 : Wing bases of Paleozoic insects. A, †Palaeodictyoptera Dunbaria quinquefasciata (Martynov, 1940), hindwing, PIN No. 1631/311; B, Dictyoptera Phyloblatta gaudryi Agnus 1903, forewing, MNHNF-R51244; C, 'Protelytroptera' Protelytron furcatum Carpenter, 1939, Paratype MCZ 3885; D, †Paoliidae Darekia sanguinea Prokop et al., 2012, forewing, MP ISEA I-F/MP/1488/14a/08. (copyright A, D Jakub Prokop; B, Gaelle Doitteau E-recolnat, MNHN; C, Museum of Comparative Zoology, Cambridge, USA). Scale bars $=2 \mathrm{~mm}$. 3C), dobsonflies (Megaloptera: Corydalidae, Sialidae) (Fig. 3D), snakeflies (Raphidioptera),

183 lice and thrips (Psocodea and Thysanoptera) (Fig. 4).

184 We also identified the PCu bulla in the following fossils: a "six-winged insects"

185 (Palaeodictyoptera) (Fig. 6A), stem Dictyoptera (roachoids) (Fig 6B), Paoliidae (Fig. 6D),

186 Archaeorthoptera, Hypoperlida and Permopsocida. Extant Dermaptera have a much reduced

187 forewing venation that is hard to interpret but it is not the case of their putative stem group, the 
'Protelytroptera' (Béthoux et al., 2016). A representative of the 'Protelytroptera' shows a strongly convex and curved structure from which two PCu veins emerge (Fig. 6C). In all the observed insects, only two or three branches emerge from the PCu bulla, and these are generally all convex, see the new proposal of pattern of venation Fig. 7A.

The only insects for which this vein could not be formerly identified are angel insects (Zoraptera) and dragonflies (Odonata). Zoraptera have a very simplified venation with only three main veins, none of which emerge from a bulla typical of the PCu. The absence of the particular PCu structure could be however explained by the reduced 'anal'/posterior area of the wing. In the Odonata there is also no particular convex and curved bulla posterior of the cubital veins; we observed however a vein forked into an anterior convex branch and a posterior concave branch that emerges from a bulla that is in a very basal position (Jacquelin et al., 2018); posterior to this vein, there is only a membranule (small membrane at the postero-basal angle of wing) with very weak veinlets (in some fossil Isophlebioidea) or no vein at all. This forked vein corresponds to the anal vein followed by the 'jugal' area of the Polyneoptera. Thus the postcubital vein and bulla could be absent in the order Odonata.

Overall, we observed a PCu in 63 of the 74 observed Pterygota, covering 23 of the 29 examined orders, using both microtomography tools and stereomicroscopy. Only two orders lack this vein (Zoraptera and Odonata), and we have yet to clarify the situation for three extant orders (Ephemeroptera, Diptera, Hymenoptera).

\section{Taxa with unclear results:}

The observation of wing venations revealed challenging for Ephemeroptera, Hymenoptera, and

Diptera. We were thus unable to unambiguously conclude about the presence of a PCu for those taxa. Surprisingly, CT scan analysis was particularly difficult for Ephemeroptera and it was not possible to conclude unambiguously using only stereomicroscopy observations. In Odonata, extant taxa have no visible $\mathrm{PCu}$, but we currently lack Paleozoic Odonatoptera showing the 
or never acquired in this lineage. Extant and fossil Ephemeroptera and Odonatoptera will thus

215 be investigated more in depth in a second step. In Palaeodictyopteroid orders, the situation is unsettled for three of the four orders (Megasecoptera, Dicliptera and Diaphanopterodea, sensus Prokop \& Engel, 2019) due to the lack of adequate fossils. In Hymenoptera, the PCu and anal veins are apparently strongly reduced, whereas in Diptera the anal veins, $\mathrm{PCu}$ and $\mathrm{Cu}$ seem to be fused at wing base. Our observations must be confirmed with additional 3D tomography reconstructions. These clarifications will not, however, change our conclusions on the origin of the PCu because of the derived positions of Hymenoptera and Diptera.

Ancestral state reconstruction - origin of the PCu:

223 Parsimoniously mapping the character 'presence of the $\mathrm{PCu}$ ' on a phylogenetic tree, we observed that the 'ancestral' presence of the $\mathrm{PCu}$ in all Pterygota is the most parsimonious hypothesis (only two reversals) to explain insect venation (Fig 7B); the opposite hypothesis ('ancestral' absence of PCu in Neoptera) implies four independent gains of the PCu. Because the existence of a $\mathrm{PCu}$ is still unclear for a few taxa, we hypothesized that those taxa lack a $\mathrm{PCu}$ and run a second ancestral state reconstruction. In this very hypothetical scenario, an ancestral presence of the $\mathrm{PCu}$ for Pterygota cannot be ruled out (ambiguous reconstruction for the Pterygota and Neoptera nodes). This ambiguous reconstruction only holds if 'Protelytroptera' 231 are monophyletic, which is unsure (Béthoux et al., 2016). If 'Protelytroptera' are paraphyletic, then the scenario with an ancestral presence of the $\mathrm{PCu}$ is more parsimonious. Overall, our results support a single origin of the $\mathrm{PCu}$. 

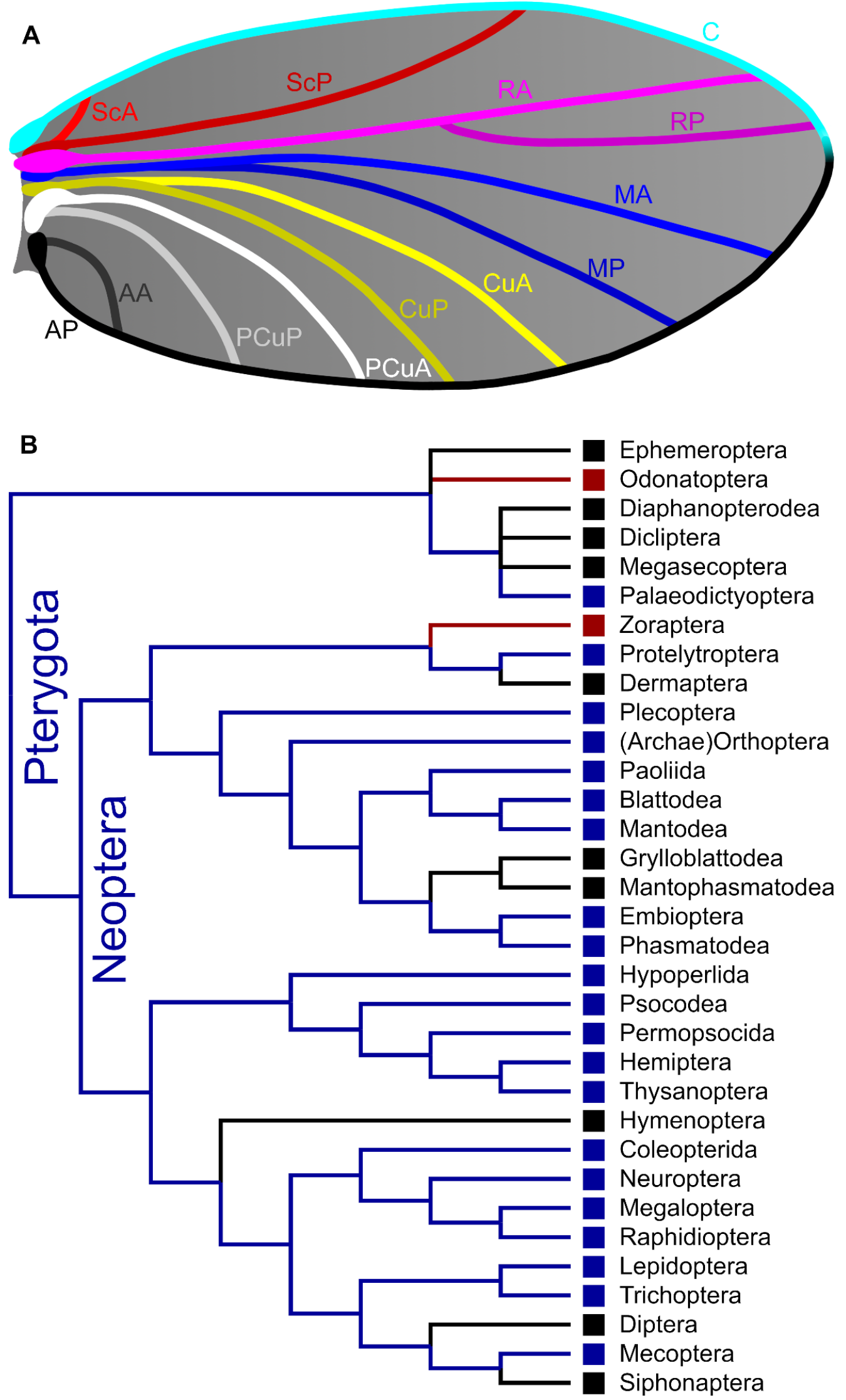

Fig. 7 : A, Proposed general pattern of insect wing venation with $P C u$ veins. Posterior branches are in darker colors than anterior branches. $B$, Phylogenetic inference in parsimony of the presence of the $P C u$ vein in Pterygota. Clades with PCu are in dark blue, those without are in red, and clades where the situation in unclear are in dark. (Archae)Orthoptera comprise extant Orthoptera and stem-lineage. 
The PCu and its implications:

Our results support Snodgrass (1935), Emeljanov (1977), Brodsky (1994), and Li et al. (2018) about the existence of a postcubital vein, independent of the cubital and the anal veins. These three veins emerge from three independent bullae. We go further, however, demonstrating that a majority of orders have a $\mathrm{PCu}$ and that the situation is even more complex than supposed by these authors. They generally considered that the $\mathrm{PCu}$ is not fused or closely adjacent to the branch(es) of the cubital system. Emeljanov (1977) and Brodsky (1994) thought that the PCu is a simple vein, posterior to $\mathrm{CuP}$, in all insects. Li et al. (2018) stated that the anal veins of Comstock-Needham should be interpreted as two independent main veins, their PCu and 'vannal' veins, on the basis of a supposed correspondence between the trachea and the veins in Blattodea. In fact, in many neopteran orders, the $\mathrm{PCu}$ is forked with its anterior branch appressed or partly fused to the CuP [e.g., Dictyoptera, for which Kukalová-Peck (1992) indicated a fusion between her 'CuP' and 'AA1' $(=\mathrm{PCu})]$.

The presence of the $\mathrm{PCu}$ also implicates that the anal area is smaller than previously suggested, which has implication on the evolution of flight and notably on the 'umbrella effect' (sensu Wootton, 1992: 131): "the soft vannus is supported by a series of unbranched anal and jugal veins radiating from the base." In Holometabola, the anal area is often reduced to only one vein. In Plecoptera, the anal area is strongly reduced in some species (e.g. Filchneria olgae (McLachlan, 1875)) and strongly developed with numerous veins associated to a reduced postcubital area in others (e.g. Eusthenia spectabilis Westwood, 1832) (Fig. 8). In some groups, such as Blattodea and Palaeodictyoptera, in which the 'anal area' is considered as very developed, the existence of the PCu vein modifies the interpretation/identities/homologies of 'anal area' veins. The Palaeodictyoptera have numerous anal and post-cubital veins, while Blattodea have few post-cubital veins and several anal veins. So, the recognition of the $\mathrm{PCu}$ as an independent vein sheds a new light on some cases of evolutionary convergences for the 'umbrella effect' (Desutter-Grandcolas et al., 2005; Wootton, 1992). 


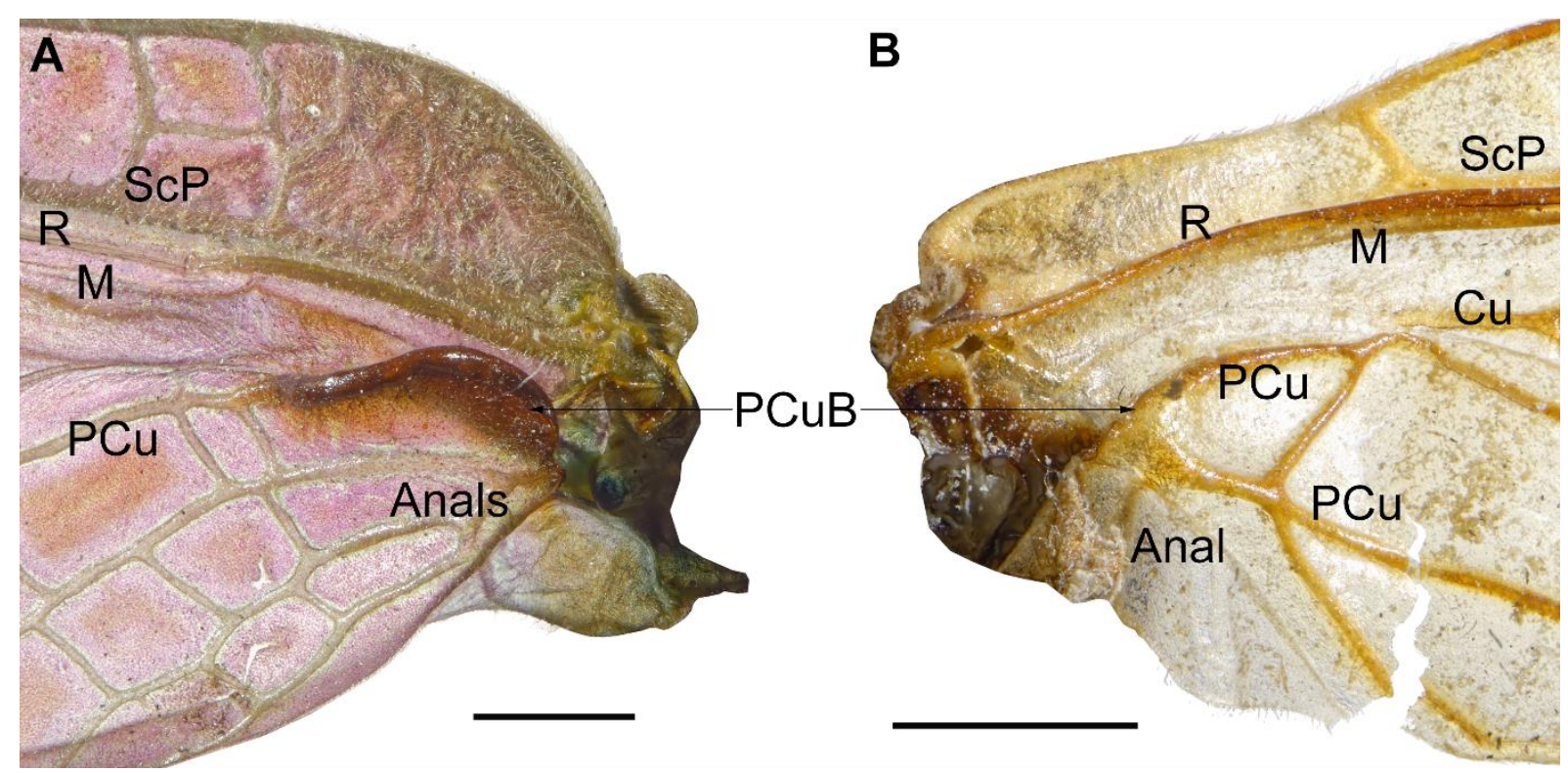

Fig. 8 : Forewing bases, photographs, dorsal views. Plecoptera. A, Eustheniidae Eusthenia spectabilis Westwood, 1832, Perlodidae Filchneria olgae (McLachlan, 1875). (copyright Thomas Schubnel). Scale bars $=1 \mathrm{~mm}$.

The specific case of Phasmatodea:

The extant Phasmatodea show an unusual forewing venation in which the main veins are

difficult to recognize. Ragge (1955) proposed a pattern based on a putative correspondence between veins and trachea, that was questioned by Nel \& Delfosse (2011) and Wang et al. (2014) on the basis of the study of the venation of Mesozoic taxa currently attributed to the stem group of Phasmatodea. These last authors considered that these fossils had venations of archaeorthopteran type (sensu Béthoux \& Nel, 2002), but this last pattern was not recovered in extant stick insects. After our CT reconstructions, extant stick insects have a median vein extremely reduced and appressed to the radial vein and a simple vein $\mathrm{Cu}$, completely separated from the median and radial veins, either only present at the extreme wing base and immediately independent from PCu (e.g., Tropidoderus childrenii Gray, 1833). The PCu structure consists

273 in two clearly convex veins, emerging from a bulla in domed structure, independent of cubital and anal bullae. Previous authors considered these two PCu veins as cubital veins (Ragge, 275 1955), or anal veins (Nel \& Delfosse, 2011). Thus the extant stick insects have an extremely particular forewing venation unique among all the Pterygota, with the median and cubital veins 
nearly absent. This venation is completely different from the pattern of the Archaeorthoptera (incl. extant Orthoptera) that have a basal fusion of $\mathrm{R}, \mathrm{M}, \mathrm{CuA}$, and a three-branched $\mathrm{CuP}$. These results will be used to re-investigate the changes in the wing venation between the alleged Mesozoic stem Phasmatodea and the extant stick insects.

\section{Conclusion}

Three-D X-ray tomography and reconstructions are very efficient to help determining the homologies of wing venation among insects, as already shown in recent studies (DesutterGrandcolas et al., 2017; Jacquelin et al., 2018). Here, it allowed us to demonstrate the existence of a $\mathrm{PCu}$ vein in most insect orders, and suggest that this structure most likely originated only once in insects. This result has important consequences for evolutionary analyses in these organisms. Until now, the same homologous vein was named AA1 for Orthoptera and PCu for Hemiptera for example, a situation hindering comparative analyses. The case of the stick insects shows that it should help to solve long-lasting evolutionary problems. It remains to determine if all Palaeoptera (extant and/or fossil) have a PCu vein or not, viz. the other Palaeodictyopterida orders Megasecoptera, Dicliptera, and Diaphanopterodea, the Carboniferous stem Odonatoptera and the fossil and extant Panephemeroptera. The presence of a $\mathrm{PCu}$ could constitute a synapomorphy of the Neoptera + Palaeodictyopterida, supported by the recently performed phylogenetic analysis of Sroka et al. (2015), and potentially absent in the Odonatoptera and Panephemeroptera. This result would be pivotal to continue unlocking crucial homology issues in insect wing venation, ultimately allowing integrating extant and fossil insects at an order level in phylogenetic analyses, a work impossible to achieve under the current state of the art. 


\section{Acknowledgements}

The authors are grateful to Ricardo Perez de la Fuente for access to the collection of Museum of Comparative Zoology (Cambridge, MA, USA) and to Alexander Rasnitsyn and his colleagues for access to the Tshekarda collection housed at Laboratory of Paleoentomology of the Russian Academy of Sciences (Moscow, Russia). We thank the President and Fellows of Harvard College for permission to use MCZ copyrighted material. J.P. gratefully acknowledges the research support from Grant Agency of the Czech Republic (No. 18-03118S). We thank a lot Renaud Boistel (Univ. Poitiers) for help to access the $\mu \mathrm{CT}$-scan and during the acquisition, Alberto Bravin and Alberto Mittone (ESRF, Grenoble) for the acquisition in ID-17 beamline, and Miguel Garcia-Sanz (OMSI) for AST-RX acquisition at MNHN. This work was supported by the French State, managed by the National Research Agency under the 'Investments for the future' program, ANR-11-INBS-0004-RECOLNAT. A.M. acknowledges financial support from the European Union (ERDF) and 'Région Nouvelle Aquitaine'.

\section{References}

Béthoux, O., Llamosi, A. \& Toussaint, S. (2016) Reinvestigation of Protelytron permianum (Insecta; Early Permian; USA) as an example for applying reflectance transformation imaging to insect imprint fossils. Fossil Records, 20, 1-7.

Béthoux, O. \& Nel, A. (2002) Venation pattern and revision of Orthoptera sensu nov. and sister groups. Phylogeny of Palaeozoic and Mesozoic Orthoptera sensu nov. Zootaxa, 96, 188.

Brodsky, A.K. (1994) The evolution of insect flight. Oxford University Press: Oxford / New York / Tokyo, xiii + 229 pp.

Chapman, R.F. (1998) The insects structure and function. Chapter The head. Cambridge University Press, 4th Edition. 
Comstock, J.H. 1918. The wings of insects. Comstock Publishing Co. (publ.) Ithaca, New York:

$$
\text { xviii }+430 \text { pp. }
$$

Comstock, J.H. \& Comstock, A.B. (1895) A manual for the study of insects. Ithaca, New York, 7-701.

Comstock, J.H. \& Needham, J.G. (1898) The wings of insects. An introduction to the study of the homologies of the wing-veins. The American Naturalist, 32, 43-48, 81-89, 231257, 335-340, 413-424, 561-565, 769-777, 903-911.

Comstock, J.H. \& Needham, J.G. (1899) The wings of insects. Chapter 4. The specialization of wings by addition. The American Naturalist, 33, 117-126, 573-582, 845-860.

Desutter-Grandcolas, L., Legendre, F., Grandcolas, P., Robillard, T., \& Murienne, J. (2005) Convergence and parallelism: is a new life ahead of old concepts? Cladistics, 21, 5161.

Desutter-Grandcolas, L., Jacquelin, L., Hugel, S., Boistel, R., Garrouste, R., Henrotay, M., Warren, B.H., Chintauan-Marquier, I.C., Nel, P., Grandcolas, P. \& Nel, A. (2017) 3-D imaging reveals four extraordinary cases of convergent evolution of acoustic communication in crickets and allies (Insecta). Scientific Reports, 7 (1) (7099), 1-8.

Emeljanov, A.F. (1977) Homology of wing structures in the cicada and the primitive Polyneoptera. Trudy Vsesofuznogo Entomologicheskogo Obshchestva [Proceedings of Allunion Entomological Society], 58, 3-48. (in Russian)

Forbes, W.T.M. (1943) The origin of wings and venational types in insects. American Midland Naturalist, 29, 381-405.

Franielczyk-Pietyra, B., \& Wegierek, P. (2019) The forewing of Cacopsylla mali (Schmidberger 1836) (Hemiptera, Sternorrhyncha) - a morphological and histological study. Zoologischer Anzeiger, 278, 95-100. 
Fraser, F.C. (1938) A note on the fallaciousness of the theory of pretracheation of the venation of Odonata. Proceedings of the Royal Entomological Society, London, (A), 13, 60-70.

Hamilton, K.G.A. (1972) The insect wing, Part 2. Vein homology and the archetypal insect wing. Journal of the Kansas Entomological Society, 45, 54-58.

Huang, Di-Ying, Bechly, G., Nel, P., Engel, M.S., Prokop, J., Azar, D., Cai, Chen-Yang, van de Kamp, T., Staniczek, A.H., Garrouste, R., Krogmann, L., dos Santos Rolo, T., Baumbach, T., Ohlhoff1, R., Shmakov, A.S., Bourgoin, T., \& Nel, A. (2016) New fossil insect order Permopsocida elucidates major radiation and evolution of suction feeding in hemimetabolous insects (Hexapoda: Acercaria). Scientific Reports, 6 (23004), 1-9.

Ivanov, V.D. (1985) Structure and function of wing articulation of caddisflies. 1. Ground plan. Vestnik Leningradskogo Universiteta Biologiya, 1985, 3-12. (in Russian)

Ivanov, V.D. (1995) Comparative analysis of wing articulation in archaic Lepidoptera. Entomological Review, 74, 32-53.

Jacquelin, L., Desutter-Grandcolas, L., Chintauan-Marquier, I., Boistel, R., Zheng, Daran, Prokop, J. \& Nel, A. (2018) New insights on basivenal sclerites using 3D tools and homology of wing veins in Odonatoptera (Insecta). Scientific Reports, 8 (238), 1-7.

Kukalová-Peck, J. (1991) Fossil history and the evolution of hexapod structures. In Insects of Australia, I.D. Naumann, ed. (Melbourne: Melbourne University Press, CSIRO), pp. $141-179$.

Lameere, A. (1922) Sur la nervation alaire des insectes. Bulletin de la Classe des Sciences, Académie Royale de Belgique, (5), 8, 138-149.

Li, X.-R., Zheng, Y.-H., Wang, C.-C. \& Wang, Z.-Q. (2018) Old method not old-fashioned: parallelism between wing venation and wing-pad tracheation of cockroaches and a revision of terminology. Zoomorphology, 137, 519-533. 
Matsuda, R. (1970) Morphology and evolution of the insect thorax. Memoirs of the Entomological Society of Canada, 102 (suppl. 76), 1-431.

Misof, B., Liu, S.-1., Meusemann, K., Peters, R.S., Donath, A., Mayer,C., Frandsen, P.B., Ware, J., Flouri, T., Beutel, R.G., Niehuis, O., Petersen, M., Izquierdo-Carrasco, F., Wappler, T., Rust, J., the 1KITE consortium (83 other authors), Wang, J., Kjer, K.M. \& Zhou, X. (2014) Phylogenomics resolves the timing and pattern of insect evolution. Science, 346 (6210), 763-767.

Nel, A. \& Delfosse, E. (2011) A new Chinese Mesozoic stick insect. Acta Paleontologica Polonica, 56, 429-432.

Nel, A., Prokop, J., Nel, P., Grandcolas, P., Huang, Di-ying, Roques, P., Guilbert, E., Dostál, O. \& Szwedo, J. (2012) Traits and evolution of wing venation pattern in paraneopteran insects. Journal of Morphology, 273, 480-506.

Nixon, K.C. (2002). WinClada, version 1.00. 08. Published by the author, Ithaca, NY, 734745.

Prokop, J., \& Engel, M.S., 2019. Palaeodictyopterida. Current Biology, 29, R307-R309.

Prokop, J., Pecharová, M., Nel A. \& Hörnschemeyer, T. (2018) The wing base of the palaeodictyopteran genus Dunbaria Tillyard: Where are we now? Arthropod Structure \& Development, 47, 339-351.

Prokop J., Krzeminski W., Krzeminska E., Hörnschemeyer T., Ilger J.-M., Brauckmann C., Grandcolas P. \& Nel A. (2014) Late Palaeozoic Paoliida is the sister group of Dictyoptera (Insecta: Neoptera). Journal of Systematic Palaeontology, 12, 601-622.

Prokop, J., Pecharová, M., Garrouste, R., Beattie, R., Chintauan-Marquier, I.C., \& Nel, A. (2017) Redefining the extinct orders Miomoptera and Hypoperlida as stem acercarian insects. BMC Evolutionary Biology, 17 (205), 1-20. 
Ragge, D.R. (1955) The wing-venation of the order Phasmida. Transactions of the Royal Entomological Society, 106, 375-392.

Séguy, E. (1959) Introduction à l'étude morphologique de l'aile des insectes. Mémoires du Muséum National d'Histoire Naturelle, Paris, (A), Zoologie, 21, 1-248.

Smart, J. (1956) A note on insect wing veins and their tracheae. Quarterly Journal of Microscopical Science, 97, 535-539.

Snodgrass, R.E. (1935) Principle of insect morphology. McGraw-Hill (publ.), New York, ix + $667 \mathrm{pp}$.

Sroka, P., Staniczek, A.H. \& Bechly, G. (2015) Revision of the giant pterygote insect Bojophlebia prokopi Kukalová-Peck, 1985 (Hydropalaeoptera: Bojophlebiidae) from the Carboniferous of the Czech Republic, with the first cladistic analysis of fossil palaeopterous insects. Journal of Systematic Palaeontology, 13, 963-982.

Wang, Mao-min, Béthoux, O., Bradler, S., Jacques, F.M.B., Cui, Yingying \& Ren, D. (2014) Under cover at pre-angiosperm times: a cloaked phasmatodean insect from the Early Cretaceous Jehol biota. PlosOne, 9 (3) (e91290), 1-10.

Wang, Yanhui, Engel, M.S., Rafael, J.A., Wu, Hao-yang, Rédei, D., Xie, Qiang, Wang, Gang, Liu, Xiao-guang \& Bu, Wen-jun (2016) Fossil record of stem groups employed in evaluating the chronogram of insects (Arthropoda: Hexapoda). Scientific Reports, 6 (38939), 1-12.

Whitten, J.M. (1962) Homology and development of insect wing tracheae. Annals of the Entomological Society of America, 55, 288-295.

Wipfler, B., Letsch, H., Frandsen, P.B., Kapli, P., Mayer, C., Bartel, D., Buckley, T.R., Donath, A., Edgerly-Rooks, J.S., Fujita, M., Liu, Shanlin, Machida, R., Mashimo, Y., Misof, B., Niehuis, O., S. Peters, R.S., Petersen, M., Podsiadlowski, L., Schütte, K., Shimizu, S., Uchifune, T., Wilbrandt, J., Yan, E., Zhou, Xin \& Simon, S. (2019) Evolutionary history 
of Polyneoptera and its implications for our understanding of early winged insects. Proceedings of the National Academy of Sciences, 116, 3024-3029.

425 Wootton, R.J. (1979) Function, homology and terminology in insect wing. Systematic 426 Entomology, 4, 81-93.

427 Wootton, R.J. (1992) Functional morphology of insect wings. Annual Review of Entomology, 428 37, 113-140. 


\section{Supplementary material}

\section{Material and methods}

Abbreviations of institutions: MNHN (Muséum national d'Histoire naturelle, Paris); NIGP (Nanjing Institute of Geology and Paleontology, Academia Sinica, China); PIN (Laboratory of Arthropods, Palaeontological Institute, Russian Academy of Sciences, Moscow); MCZ (Museum of Comparative Zoology, Cambridge, USA); MP ISEA (Natural History Museum of the Institute of Systematics and Evolution of Animals, Polish Academy of Science, Kraków, Poland); IRSNB (Institut Royal d'Histoire Naturelle de Belgique, Bruxelles); UP (Université de Poitiers, Poitiers).

\section{Observed specimens:}

Supplementary table 1. List of observed specimens. All extant dried specimens are in the entomology collection of the Muséum national d'Histoire naturelle (MNHN).

\begin{tabular}{|c|c|c|c|c|c|}
\hline Order & Species & \begin{tabular}{|c|} 
X-ray \\
scanned
\end{tabular} & \begin{tabular}{|c|} 
PCu \\
identified
\end{tabular} & Inventory number & Period \\
\hline$\dagger$ Palaeodictyoptera & $\begin{array}{c}\dagger \text { Dunbaria quinquefasciata } \\
\text { (Martynov, 1940) }\end{array}$ & & Yes & PIN 1631/311 & Permian \\
\hline$\dagger$ Megasecoptera & $\begin{array}{c}\dagger \text { Scytohymen extremus } \\
\text { Martynov, } 1937\end{array}$ & & $?$ & PIN 4987/113 & Permian \\
\hline \multirow[t]{3}{*}{ Ephemeroptera } & Ephemera danica Müller, 1764 & UP & $?$ & MNHN EP578 & Modern \\
\hline & $\begin{array}{c}\text { Oligoneuriella rhenana } \\
\text { (Imhoff, 1852) }\end{array}$ & & $?$ & & Modern \\
\hline & Baetis sp. & & $?$ & & Modern \\
\hline \multirow[t]{2}{*}{ Odonata } & Aeshna cyanea (Müller, 1764) & & No & & Modern \\
\hline & Aeshna isoceles Müller, 1767 & UP & No & & Modern \\
\hline
\end{tabular}




\begin{tabular}{|c|c|c|c|c|c|}
\hline$\dagger$ Protelytroptera & $\begin{array}{c}\dagger \text { Protelytron furcarum } \\
\text { Carpenter, } 1939\end{array}$ & & Yes & MCZ 3885 & Permian \\
\hline Zoraptera & $\begin{array}{l}\text { Zorotypus caudelli Karny, } \\
1927\end{array}$ & & No & & Modern \\
\hline \multirow[t]{3}{*}{ Plecoptera } & $\begin{array}{c}\text { Perla marginata (Panzer, } \\
1799)\end{array}$ & ESRF & Yes & MNHN EP 4340 & Modern \\
\hline & $\begin{array}{c}\text { Eusthenia spectabilis } \\
\text { Westwood, } 1832\end{array}$ & & Yes & & Modern \\
\hline & $\begin{array}{c}\text { Filchneria olgae (McLachlan, } \\
1875)\end{array}$ & & Yes & & Modern \\
\hline Panorthoptera & $\dagger$ Cacurgus sp. & & Yes & MNHN F A 70497 & Carboniferous \\
\hline \multirow[t]{6}{*}{ Orthoptera } & Brachytrupes sp. & & Yes & & Modern \\
\hline & $\begin{array}{c}\text { Chorthippus scalaris (Fischer } \\
\text { von Waldheim, 1846) }\end{array}$ & & Yes & & Modern \\
\hline & Gryllacropsis sp. & MNHN & Yes & $\begin{array}{c}\text { MNHN EO ENSIF } \\
3080\end{array}$ & Modern \\
\hline & $\begin{array}{c}\text { Locusta migratoria (Linnaeus, } \\
1758)\end{array}$ & & Yes & & Modern \\
\hline & \begin{tabular}{|c|} 
Phymateus saxosus Coquerel, \\
1861
\end{tabular} & & Yes & & Modern \\
\hline & Trigonopteryginae sp. & MNHN & Yes & $\begin{array}{c}\text { MNHN EO CAELIF } \\
3000\end{array}$ & Modern \\
\hline \multirow[t]{2}{*}{ Phasmatodea } & $\begin{array}{c}\text { Phasma gigas (Linnaeus, } \\
1758)\end{array}$ & MNHN & Yes & $\begin{array}{c}\text { MNHN EO PHAS } \\
1083\end{array}$ & Modern \\
\hline & Phyllium sp. & & Yes & & Modern \\
\hline
\end{tabular}




\begin{tabular}{|c|c|c|c|c|c|}
\hline & $\begin{array}{c}\text { Tropidoderus childrenii Gray, } \\
1833\end{array}$ & & Yes & & Modern \\
\hline \multirow[t]{2}{*}{ Embioptera } & $\begin{array}{c}\text { Aposthonia ceylonica } \\
\text { Enderlein, } 1912\end{array}$ & ESRF & Yes & MNHN EP 4342 & Modern \\
\hline & $\begin{array}{l}\text { Berlandembia berlandi (Navás, } \\
\text { 1922) }\end{array}$ & & Yes & & Modern \\
\hline$†$ Paoliida & $\begin{array}{c}\dagger \text { Darekia sanguinea } \text { Prokop et } \\
\text { al., } 2012\end{array}$ & & Yes & $\begin{array}{c}\text { MP ISEA } \\
\text { I-F/MP/1488/14a/08 }\end{array}$ & Carboniferous \\
\hline \multirow[t]{2}{*}{ Dictyoptera } & $\begin{array}{c}\dagger \text { Miroblattites costalis } \\
\text { (Laurentiaux-Vieira \& } \\
\text { Laurentiaux, 1987) }\end{array}$ & & Yes & IRSNB No. 15.576 & Carboniferous \\
\hline & $\begin{array}{c}\dagger \text { Phyloblatta gaudryi Agnus } \\
1903\end{array}$ & & Yes & MNHN-F-R51244 & Carboniferous \\
\hline \multirow[t]{6}{*}{ Blattodea } & Euphyllodromia sp. & & Yes & & Modern \\
\hline & $\begin{array}{c}\text { Mastotermes darwiniensis } \\
\text { Froggatt, } 1897\end{array}$ & & Yes & & Modern \\
\hline & Megaloblatta sp. & & Yes & & Modern \\
\hline & $\begin{array}{l}\text { Periplaneta americana } \\
\text { (Linnaeus, 1758) }\end{array}$ & ESRF & Yes & MNHN EP 4339 & Modern \\
\hline & $\begin{array}{l}\text { Polyphaga aegyptiaca } \\
\text { (Linnaeus, 1758) }\end{array}$ & & Yes & & Modern \\
\hline & Protagonista sp. & & Yes & & Modern \\
\hline \multirow[t]{2}{*}{ Mantodea } & $\begin{array}{l}\text { Acanthops fuscifolia Olivier, } \\
\qquad 1792\end{array}$ & & Yes & & Modern \\
\hline & Amorphoscelis sp. & & Yes & & Modern \\
\hline
\end{tabular}




\begin{tabular}{|c|c|c|c|c|c|}
\hline & \begin{tabular}{|c|} 
Chaeteessa caudata Saussure, \\
1871
\end{tabular} & & Yes & & Modern \\
\hline & Choeradodis sp. & & Yes & & Modern \\
\hline & $\begin{array}{c}\text { Hymenopus coronatus Olivier, } \\
1792\end{array}$ & & Yes & & Modern \\
\hline & Metallyticus sp. & & Yes & & Modern \\
\hline & $\begin{array}{c}\text { Pnigomantis medioconstricta } \\
\text { Westwood, } 1889\end{array}$ & & Yes & & Modern \\
\hline & $\begin{array}{l}\text { Stagmatoptera supplicaria } \\
\text { (Burmeister, 1838) }\end{array}$ & UP & Yes & MNHN EP 577 & Modern \\
\hline$\dagger$ Hypoperlida & $\begin{array}{c}\dagger \text { Hypoperla elegans Martynov, } \\
1928\end{array}$ & & Yes & PIN 3353/415 & Permian \\
\hline Psocoptera & $\begin{array}{c}\text { Loensia fasciata (Fabricius, } \\
\text { 1787) }\end{array}$ & & Yes & & Modern \\
\hline$†$ Permopsocida & $\begin{array}{c}\dagger \text { Psocorrhyncha burmitica } \\
\text { Huang et al., } 2016\end{array}$ & & Yes & NIGP161473 & Cretaceous \\
\hline Thysanoptera & $\begin{array}{c}\text { Megalothrips delmasi } \\
\text { Bournier, } 1956\end{array}$ & & Yes & & Modern \\
\hline \multirow[t]{3}{*}{ Hemiptera } & $\begin{array}{l}\text { Lyristes plebejus (Scopoli, } \\
\text { 1763) }\end{array}$ & & Yes & & Modern \\
\hline & $\begin{array}{l}\text { Phrictus auromaculatus } \\
\text { Distant, } 1905\end{array}$ & & Yes & & Modern \\
\hline & $\begin{array}{c}\text { Afrolidia boukokoensis } \\
\text { Nielson, } 1992\end{array}$ & & Yes & & Modern \\
\hline
\end{tabular}




\begin{tabular}{|c|c|c|c|c|}
\hline & \begin{tabular}{|c|} 
Ptyelus flavescens (Fabricius, \\
1794)
\end{tabular} & & Yes & Modern \\
\hline & $\begin{array}{c}\text { Cacopsylla mali } \\
\text { (Schmidberger, 1836) }\end{array}$ & & Yes & Modern \\
\hline & Halyomorpha halys Stål, 1855 & & Yes & Modern \\
\hline \multirow[t]{2}{*}{ Hymenoptera } & Xyela julii Brébisson, 1818 & & $?$ & Modern \\
\hline & $\begin{array}{c}\text { Urocerus gigas (Linnaeus, } \\
1758 \text { ) }\end{array}$ & & $?$ & Modern \\
\hline \multirow[t]{3}{*}{ Coleoptera } & $\begin{array}{c}\text { Cerambyx cerdo Linnaeus, } \\
1758\end{array}$ & & Yes & Modern \\
\hline & Oryctes sp. & & Yes & Modern \\
\hline & Cupes raffrayi Fairmaire, 1885 & UP & Yes & Modern \\
\hline Megaloptera & Corydalis sp. & & Yes & Modern \\
\hline \multirow[t]{3}{*}{ Neuroptera } & Cymothales sp. & & Yes & Modern \\
\hline & Glyptobasis sp. & & Yes & Modern \\
\hline & $\begin{array}{l}\text { Polystoechotes punctatus } \\
\text { Fabricius, } 1793\end{array}$ & & Yes & Modern \\
\hline Raphidioptera & $\begin{array}{l}\text { Fibla peyerimhoffi (Navás, } \\
\text { 1919) }\end{array}$ & & Yes & Modern \\
\hline \multirow[t]{3}{*}{ Trichoptera } & $\begin{array}{c}\text { Semblis phalaenoides } \\
\text { (Linnaeus, 1758) }\end{array}$ & & Yes & Modern \\
\hline & $\begin{array}{c}\text { Molanna albicans (Zetterstedt, } \\
1840)\end{array}$ & & Yes & Modern \\
\hline & $\begin{array}{c}\text { Notidobia ciliaris (Linnaeus, } \\
1760 \text { ) }\end{array}$ & & Yes & Modern \\
\hline
\end{tabular}




\begin{tabular}{|c|c|c|c|}
\hline & $\begin{array}{c}\dagger \text { Tecrotaulius proximus } \\
\text { Sukatsheva } 1973\end{array}$ & Yes & Trias \\
\hline & $\begin{array}{l}\text { Philopotamus montanus } \\
\text { (Donovan, 1813) }\end{array}$ & Yes & Modern \\
\hline \multirow[t]{3}{*}{ Lepidoptera } & $\begin{array}{c}\text { Korscheltellus lupulinus } \\
\text { (Linnaeus, 1758) }\end{array}$ & Yes & Modern \\
\hline & $\begin{array}{l}\text { Micropterix aureatella } \\
\text { (Scopoli, 1763) }\end{array}$ & Yes & Modern \\
\hline & $\begin{array}{c}\text { Agathiphaga queenslandensis } \\
\text { Dumbleton, } 1952\end{array}$ & Yes & Modern \\
\hline \multirow[t]{3}{*}{ Mecoptera } & $\begin{array}{c}\text { Harpobittacus australis Klug, } \\
1838\end{array}$ & Yes & Modern \\
\hline & Bittacus chilensis Klug, 1838 & Yes & Modern \\
\hline & $\begin{array}{c}\text { Panorpa germanica Linnaeus, } \\
1758\end{array}$ & Yes & Modern \\
\hline \multirow[t]{2}{*}{ Diptera } & Tipula maxima Poda, 1761 & $?$ & Modern \\
\hline & $\begin{array}{c}\text { Tabanus autumnalis Linnaeus } \\
1761\end{array}$ & ? & Modern \\
\hline
\end{tabular}

Imaging:

the nine specimens, for whom we report here 3D observations, were imaged under X-ray. XMT was performed according to the protocols reported in the literature (Boistel et al., 2011; Lauridsen et al., 2011; Zanette et al., 2013). At the 'PLATeforme INstrumentale d'Analyses' (PLATINA, IC2MP) of the University of Poitiers (France), we used a microtomograph RX solutions EasyTom XL Duo, using a Hamamatsu nanofocus 160 kV 8W source and a VarianPaxscan 2520DX CsI detector. At the microtomograph of the MNHN, plateform ASTRX, we 
used a v|tome|x L 240-180, GE Sensing \& Inspection Technologies phoenix x|ray. At the ESRF (Grenoble), we used the ID17 line. To be scanned, each forewing was most often separated from the body and placed in a plastic tube, parallel at the beam of CT-scan. For each specimen, the image acquisition parameters are listed in Suppl. Table 2.

3D volume rendering (Isosurface) was used to visualize the sub-set of selected voxels of the wings structure in AVIZO (FEI, Merignac, France, https://www.fei.com/software/amiraavizo/). This was performed using a manual segmentation tools with a limitation of level of grey (Supplementary Figs 1-2). The segmentation process resulted for each dataset in a 'label' dataset with the same dimensions as the corresponding slice. The microtomography analyses show the wing membrane, the ribs and thoracic basal sclerites. For convenience, we have chosen to reproduce in $3 \mathrm{D}$ models the ribs, basivenale bullae, and main veins. Most of the crossveins that were visible on tomograms were not essential for the study; therefore, they generally do not appear. In order to complete the 3D modeling, each specimen was observed under a binocular microscope, model Olympus SZX9, with a target PLAPO 1X DF-2 and Nikon SMZ25 Microscope. The wing venations were photographed using a Nikon D800 digital camera and a Nikon SMZ25 Microscope, assembled with Helicon Focus (multifocus method) and modified using Adobe Photoshop CS and DxO PhotoLab softwares.

Supplementary table 2. List of taxa and parameters for CT-scan segmentation

\begin{tabular}{|l|c|l|c|l|c|}
\hline Taxon Collection & $\begin{array}{c}\text { Accelerating } \\
\text { number }\end{array}$ & $\begin{array}{l}\text { Intensity } \\
\text { voltage }(\mathbf{k V})\end{array}$ & $\begin{array}{l}\text { Numerisation } \\
(\boldsymbol{\mu A})\end{array}$ & Number & Voxel \\
angle $\left(^{\circ}\right)$ & projections & size $(\boldsymbol{\mu m})$ \\
\hline MNHN EP578 & 70 & 27 & 360 & 1440 & 4.44 \\
\hline MHHN EO & 65 & 230 & 360 & 2300 & 32.08 \\
\hline
\end{tabular}




\begin{tabular}{|c|c|c|c|c|c|}
\hline $\begin{array}{l}\text { MNHN EO } \\
\text { CAELIF } 3000\end{array}$ & 80 & 230 & 360 & 1700 & 14.10 \\
\hline $\begin{array}{l}\text { MNHN EO } \\
\text { ENSIF } 3080\end{array}$ & 120 & 110 & 360 & 1300 & 18.44 \\
\hline MNHN EP 577 & 70 & 27 & 360 & 1440 & 6.57 \\
\hline MNHN EP 4339 & \multicolumn{4}{|c|}{ Not given } & 3.04 \\
\hline MNHN EP 4340 & \multicolumn{4}{|c|}{ Not given } & 3.04 \\
\hline MNHN EP 4342 & \multicolumn{4}{|c|}{ Not given } & 1.47 \\
\hline Aeshna isoceles & 70 & 33 & 360 & 1184 & 3.45 \\
\hline Cupes raffrayi & 80 & 26 & 360 & 2976 & 2.73 \\
\hline
\end{tabular}

\section{Discussion}

\section{Homologies of wing veins in the extant Orthoptera:}

Desutter-Grandcolas et al. (2017), in a morphological analysis of the venation of the Orthoptera:

Ensifera, considered that the singing file of the Grylloidea and Tettigonioidea is on the first anal vein, while it is on the most posterior branch of the vein $\mathrm{CuP}$ in the Gryllotalpoidea and Hagloidea. The vein they named first anal (or A1) is in fact the most anterior branch of $\mathrm{PCu}$ vein. In this particular case, it does not change much in the evolutionary consequences of the study of Desutter-Grandcolas et al. (2017), but could be more important for comparisons with the situation in other taxa, especially fossils, e.g, the Permostridulidae and the fossil taxa currently in Hagloidea (Gorochov, 1995; Béthoux et al., 2003). 


\section{References}

Béthoux, O., Nel, A., Lapeyrie, J., Gand, G. and Galtier, J. 2003. The Permostridulidae, a new enigmatic insect family from the Upper Permian of France. European Journal of Entomology, 100 (4): 581-585.

Boistel, R., Herrel, A., Lebrun, R., Daghfous, G., Tafforeau, P., Losos, J.B. \& Vanhooydonck, B. (2011) Shake rattle and roll: the bony labyrinth and aerial descent in squamates. Integrative Comparative Biology, 56, 957-968.

Desutter-Grandcolas, L., Jacquelin, L., Hugel, S., Boistel, R., Garrouste, R., Henrotay, M., Warren, B.H., Chintauan-Marquier, I.C., Nel, P., Grandcolas, P. and Nel, A. 2017. 3-D imaging reveals four extraordinary cases of convergent evolution of acoustic communication in crickets and allies (Insecta). Scientific Reports, 7(1) (7099): 1-8.

Gorochov, A.V. 1995. Sistema i evolyutsiya pryamokrylykh podotryada Ensifera (Orthoptera) [System and Evolution of the suborder Ensifera (Orthoptera).] Parts 1 and 2. Trudy Zoologicheskogo Instituta [Russian Academy of Sciences, Proceedings of the Zoological Institute], St.-Petersburg, 260: 3-224 + 261: 3-212. [in Russian]

Lauridsen, H., Hansen, K., Wang, T., Agger, P., Andersen, J.L., Knudsen, P.S., Rasmussen, A.S., Uhrenholt, L. \& Pedersen, M. (2011) Inside out: modern imaging techniques to reveal animal anatomy. PLOS ONE, 6, e17879.

Zanette, I., Daghfous, G., Weitkamp, T., Gillet, B., Adriaens, D., Langer, M., Cloetens, P., Helfen, L., Bravin, A., Peyrin, F., Baumbach, T., Dischler, J.-M., Van Loo, D., Praet, T., Poirier-Quinot, M. \& Boistel, R. (2013) Looking inside marine organisms with magnetic resonance and X-ray imaging. pp. 122-184. In: Reynaud, E.G. (ed.) Imaging marine life. Weinheim, Germany: Wiley-VCH Verlag GmbH \& Co. KgaA. 


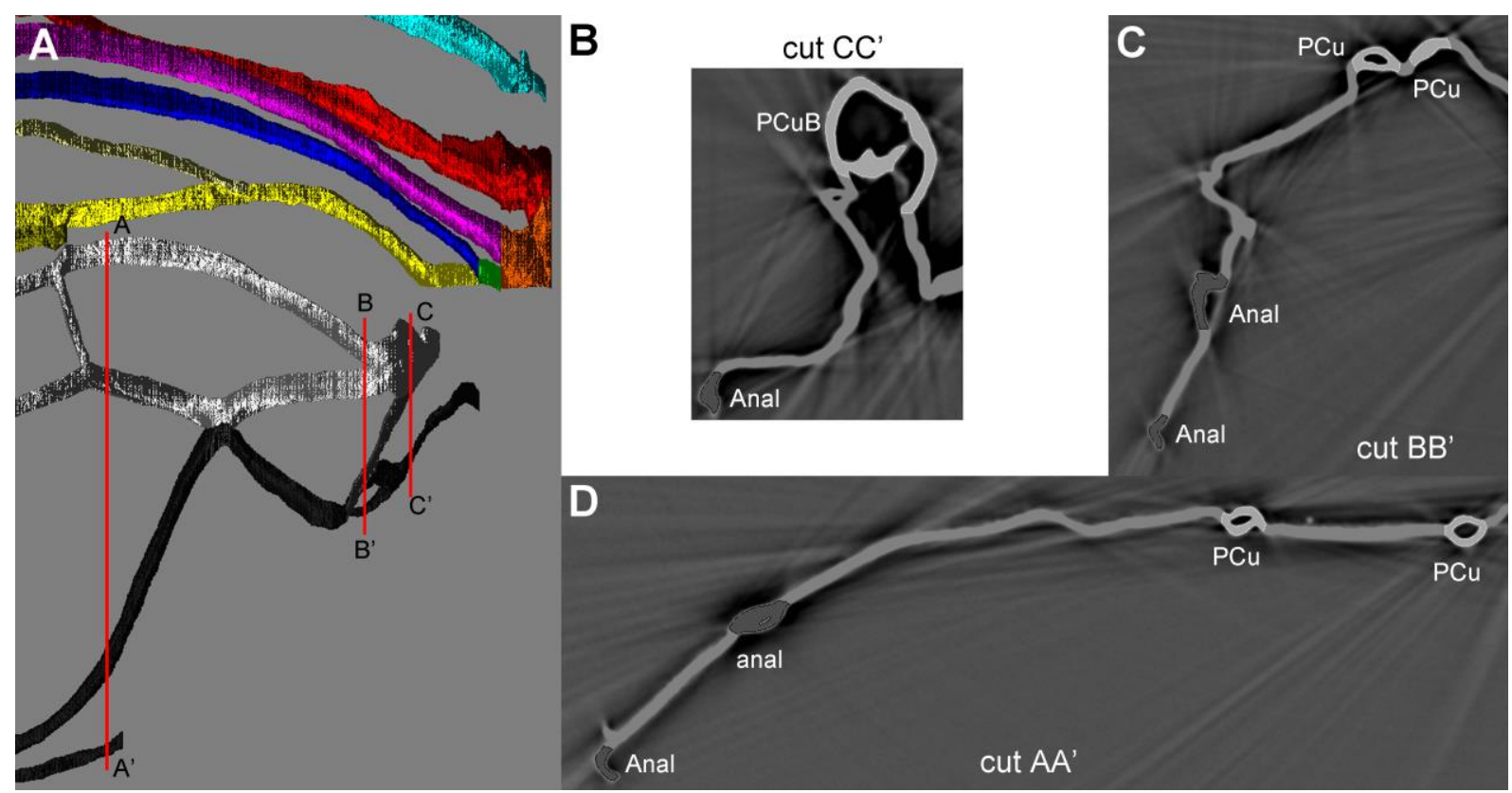

Supplementary Fig. 1. Plecoptera Perla marginata (Panzer, 1799), forewing base, 3D reconstruction, dorsal view, with three cuts showing the course of the postcubital and anal veins and bullae. A, reconstruction; B-D, cuts. (copyright Thomas Schubnel).

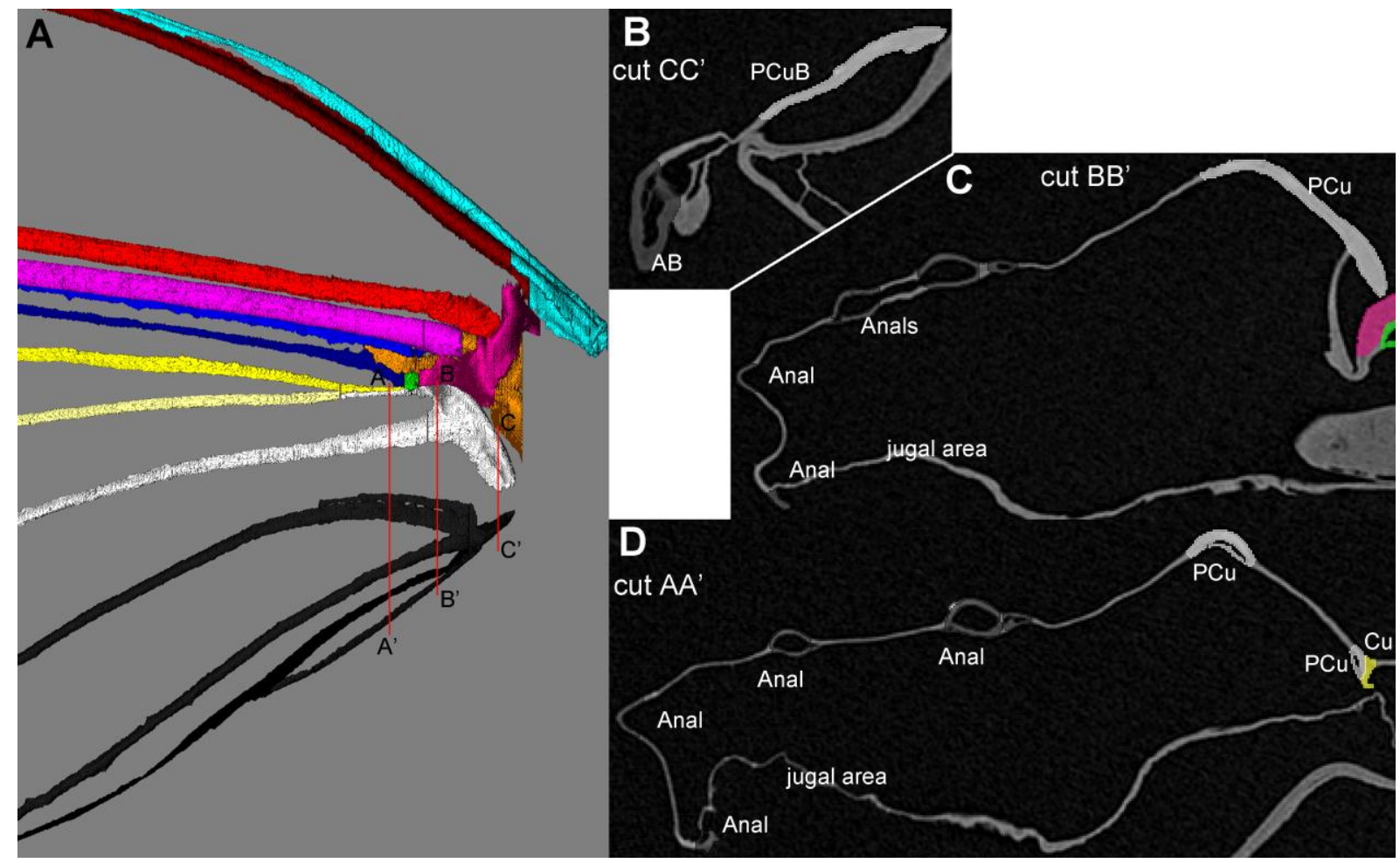

Supplementary Fig. 2. Mantodea Stagmatoptera supplicaria (Stoll, 1813), forewing base, 3D reconstruction, dorsal view, with three cuts showing the course of the postcubital and anal veins and bullae. A, reconstruction; B-D, cuts. (copyright Thomas Schubnel). 